\title{
仮想的所得再分配による不平等と幸福総和の変動
}

—2005 年 SSM 調査データを用いたシミュレーション分析——

\section{石田 淳*}

\begin{abstract}
分配原理についての規範的研究は, 近年社会学においても注目を集めるよう になった。これらの規範的な議論に対して経験科学を出発点とする社会学がな しうる貢献の 1 つの形として，ある分配原理を現実に適用した際に生じるさま ざまな社会的影響を, 社会調査デー夕をもとにして見積もる, という方向性が ありうる. 本研究はこのような基本的なアイデアのもと, 仮想的な所得再分配 によって, 人々の主観的幸福, そして主観的幸福の社会的総和がどのように変 化するかを, 2005 年 SSM 調査デー夕を用いてシミュレーション分析すること を目的とする. 本稿では平等主義の観点に立って, 段階的に完全平等へと分配 を変化させるという再分配方法を採用し, 平等化の度合いによる幸福総和（平 均）の挙動を分析する.このために, 各個人・世带のプロフィールに応じて, 所得を独立変数とする主観的幸福（生活満足得点）関数を調查デー夕から推定 し，次にこれをもとに所得再分配後の主観的幸福の変化を予測する.

結果として以下の知見が得られた．第 1 に，個人所得，世带所得いずれを対 象にした場合も，段階的平等化所得再分配の平均幸福への効果は限定的である. 第 2 に, 平等化をある程度進めたところで平均幸福改善効果に飽和点が見られ た．このことは，効率的に幸福を高めることを目的とする場合は，適度な平等 分配が効果的であることを示唆している.

キーワード : 所得再分配, 主観的幸福, 不平等
\end{abstract}

\section{1 本研究の背景と目的}

\section{1 格差と分配に対する意識}

2000 年前後から, 社会的不平等・格差の問題は大きな社会的争点となってきた. その際とくに結果の不平等に関連して, 所得の不平等度の高まりや, 所得分布上で 定義される貧困率の高まりが指摘されている1).こうした議論に呼応するように, 人々も「格差社会化」を意識しつつある. 2005 年社会階層と社会移動調查（SSM 調査）では，格差認識に関するいくつかの質問を実施している。例えば,「いまの 日本では収入の格差が大きすぎる」かと尋ねたところ， $61.1 \%$ の回答者が「そう思

\footnotetext{
* 日本学術振興会特別研究員 (PD) aishida@kwansei.ac.jp
} 
表 1 望ましい分配原理（SSM1995年，2005年調査）(\%)

\begin{tabular}{c|ccccc}
\hline & 実績 & 努力 & 必要 & 平等 & DK/NA \\
\hline 1995年 & 22.9 & 57.1 & 9.4 & 6.4 & 4.1 \\
2005年 & 26.9 & 46.6 & 10.1 & 7.2 & 9.0 \\
\hline
\end{tabular}

う」もしくは「どちらかといえばそう思う」と回答した．同様に，「10 年後の日本 は，収入の格差がいまよりも大きくなっているだろう」との見通しに対しては， $64.4 \%$ 賛同している.

一方, 格差・不平等問題の議論の背後には，どのような分配原理が望ましいかを 問う規範理論の存在が不可欠である。これに関して，1995 年と 2005 年の SSM 調 查では，直接人々に理想の分配原理を尋ねている（表 1)。95 年で $80 \%, 05$ 年でも $73.5 \%$ の々が，実績や努力という成果主義的分配原理を支持している。もっとも， その中でも 95 年から 05 年にかけて努力の支持が減り, 実績支持が若干上昇してい る。一方，平等分配支持者は 95 年，05 年ともにもっとも少ない.

しかし一方で，「政府は豊かな人からの税金を増やしてでも，恵まれない人への 福祉を充実させるべきだ」との質問には，62.5\%が賛同している，大まかなまとめ 方をすると，人々は成果主義的分配原理を理念レベルでは受け入れつつも，行き過 ぎた格差に対する是正には肯定的であり，その一方で過度な平等化には慎重である と言えるだろう。

\section{2 分配状態と幸福}

こうした経済的分配状況の変化は人々の生活の質，そしてその評価に大きく関係 する。つまり，人々の幸福に影響するのであり，人々の幸福の促進，そして不幸の 縮減を 1 つの社会的目標とするのであれば，分配と幸福の関係を具体的に見積もっ ておく必要がある。このとき，本研究では生活の質そのものではなく，「個人が自 らの生活全体の質を好意的に判断する程度」（Veenhoven 1984）である「主観的幸 福（subjective well-being）」を，分配による生活全体の変化に対する最も基本的な 反応として注目することにする.

経済的状況と主観的幸福の関係性は，これまで主観的幸福研究において主要な問 題として取り上げられてきた。ここでは，所得と主観的幸福の単純な関係を 2005 年 SSM 調查データで確認しておこう。ところで，主観的幸福の最も一般的な操作 的定義の 1 つは「生活全般の满足度」である (Veenhoven 2007) ${ }^{2)}$. SSM 調査でも 意識項目として生活満足感を尋ねており, 本研究でも「満足している」の 5 点から 「不満である」の 1 点まで， 5 つの選択肢に対応させて得点を割り当てた生活満足 得点を主観的幸福の操作的定義とする。個人所得と生活満足得点との単相関は 0.09 であり，1\%水準で有意であるもののかなり低い．一方，世帯所得との相関係 数は 0.21 であり $1 \%$ 水準で有意であった，図 1 （754 頁）は，個人所得階層と生活 


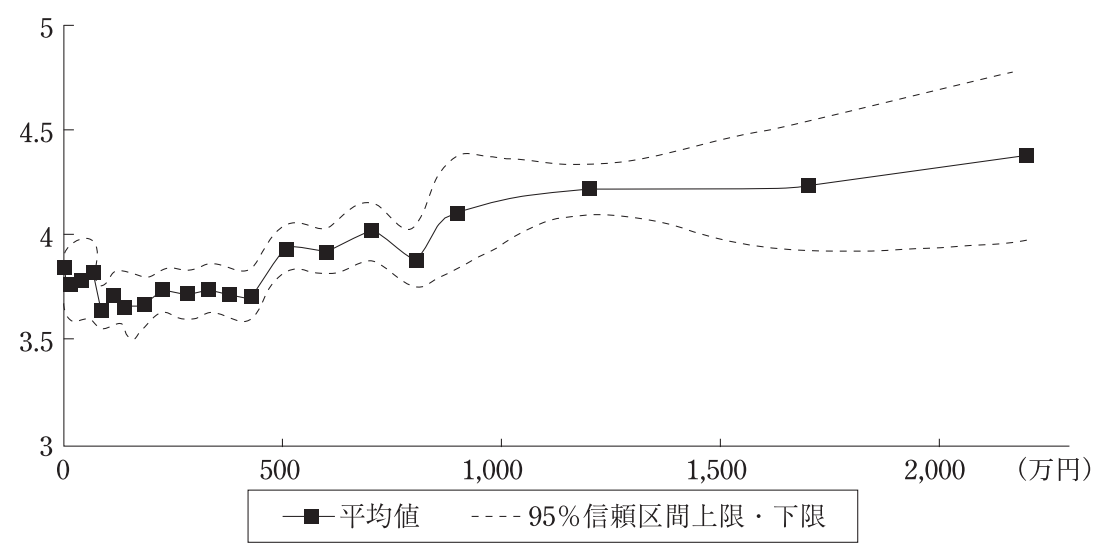

図 1 個人所得階層ごとの生活満足得点平均

満足得点平均との関係を示している3)。これによると, 500 万円あたりまでは所得 の増加に対して, 生活満足得点平均はほとんど変化しないものの, 500 万円位以上 になると右肩に上がるという傾向が見られる. また， 1,000 万円以上の生活満足得 点の上昇は緩やかである.

これまでの先行研究の結果から, 一時点の個人間比較においては, 所得と主観的 幸福との間に有意ではあるが弱い連関があることが知られている (Diener et al. 1999; Diener and Biswas-Diener 2002; Frey and Stutzer 2000=2005). ゆえに，こ こでの結果は既存の先行研究の知見と整合的である. なお, 所得の効果は他の要因 をコントロールしても残るが，失業やインフレといった他の経済的要因がより大き な影響を与えているという研究結果もある（Frey and Stutzer 2000=2005; 大竹 2004）. 所得が主観的幸福に直接的に与える影響は限定的なものであると考えられ る.

\section{3 研究の目的}

これまで厚生経済学や分配的正義論では, 分配原理についての規範理論上の議論 が繰り広げられてきた。近年社会学でもこうした議論は注目を集めているが, これ らの規範的な議論に対してあくまで経験科学を出発点とする社会学がなしうる貢献 の 1 つの形として，ある分配原理を現実に適用した際に生じるさまざまな社会的影 響を，社会調査データをもとにして見積もる，という方向性がありうる．このよう な発想をもつ研究としてはすでに，浜田・石田（2003），石田・浜田（2005）によ る仮想的機会調整分析がある。これは, J. Roemer $(1996=2001,1998)$ の機会平等 の原則に基づくある種の分配原理を適用し再分配を実施したとき, 社会的な不平等 度がどのように変化するかを分析するものであった。

本研究ではこの基本的なアイデアを継承しつつ, より踏み込んで, 仮想的な社会 
的資源の再分配による生活全体の変化に対する最も基本的な反応としての主観的幸 福の変化, そしてその社会的集積の変化に焦点を当てる. さらに, 再分配対象とし て所得（個人所得，世帯所得）を取り上げる．主観的幸福に影響を与える社会的資 源としては，社会関係資本を含めてさまざまなものがありうるが，そうした資源に も操作 $=$ 再分配可能性の高い資源とそうでない資源がある．通常，再分配の対象と してまずもって考慮の対象に入るのは，再分配可能性の高いフローとしての所得で ある.ゆえに研究の出発点としてここでは，再分配可能性の高い資源である所得の 再分配が主観的幸福に与える効果を検討することにする。まとめて言えば本研究は， 仮想的な所得再分配によって人々の主観的幸福, そして主観的幸福の社会的総和 （平均）がどのように変化するかを，2005 年 SSM 調査データを用いてシミュレー ション分析することを目的とする.

分析枠組みを, より抽象化して示せば次の通りである. 個人もしくは世帯 $i$ の所 得を $y_{i}$ とおき，主観的幸福を $w_{i}$ とする。 $w_{i}$ は $y_{i}$ の関数であると仮定する，つまり， $w_{i}=f_{i}\left(y_{i}\right)$. また, 主観的幸福の総和の指標として平均幸福 $W$ を用いる. このと き, 所得の再分配によって $W$ がどのように変化するかが, 本分析の焦点となる. ここで注意すべきは, 本研究では所得分布上の順位などの相対的な基準ではなく, 所得值そのものによって主観的幸福が決定されると仮定していることである.

ところで，Wは功利主義的社会厚生関数の一種であると見なしうる．このとき， 功利主義的に最適な分配とは何か, という問いを立てることができる. 古くは H. Sidgwick や A. C. Pegou という厚生経済学の創始期に活躍した人々がこの問いを取 り上げている. そこでは, 単調増加で限界効用瓝減的な効用関数を仮定すると, 限 界効用を等しくする分配が功利主義的社会厚生関数を最大化すること, そしてすべ ての個人の効用関数が等しいと仮定した場合, 平等分配が最適であるとの結論が導 かれている $\left(\right.$ 村上 1972) ${ }^{4}$. また, 税制論の分野では, 税による再分配の攪乱効果 を考慮に入れて課税問題を最適化問題として分析する最適課税論という理論がある (小西 1997)。こうした理論的な取り組みに対して本研究は，幸福総和を「人々の 反応の集積」と見なし，仮想的な変化を「経験的」に探求することに関心がある. そこで, 幸福関数（効用関数）をアプリオリに設定するのではなく, 経験的デー夕 に照らしてプロフィールごとに推定する5).

\section{2 分析枠組み}

\section{1 分析手順}

分析の基本的なアイデアは, 各個人・世帯のプロフィールに応じて, 所得を独立 変数とする主観的幸福関数（操作的には生活満足得点関数）を調査デー夕から推定 し，これをもとに所得再分配後の主観的幸福（生活満足得点）の変化を予測するこ とにある。

プロフィールに応じた満足得点関数の推定は一般線型モデルによって行う. 具体 
的な推定の手順と結果については 3 節で詳しく論じる. 満足得点関数の推定の後に, 所得総額不変という制約条件のもと仮想的な再分配をデー夕上で実施する ${ }^{6)}$. 本研 究で想定される仮想的再分配とは, 属性が不変のまま所得のみが税や社会保障制度 を通して再分配される事態であり, 生活満足得点の変化の予測には所得による変化 のみを加算する推定式が妥当である，そこで以下のように定義する．任意のプロフ イール $r$ の反応関数を $w=f_{r}(y)$ とする. $r$ を属性としてもつ $i$ の現時点での所得を $y_{r i}$, 生活満足得点を $w_{r i}$ とする. 再分配後の所得を $y^{\prime}{ }_{r i}$ とすると, 再分配後の生活満 足得点 $w^{\prime}{ }_{r i}$ は,

$$
w_{r i}^{\prime}=w_{r i}+f_{r}\left(y_{r i}^{\prime}\right)-f_{r}\left(y_{r i}\right)
$$

によって推定される ${ }^{7)}$.

\section{2 平均を基準とした平等化再分配法}

所得の再分配法としては, 原理的には多種多様なものが考えられ, 研究関心に応 じてそれらを試みることが可能である. 具体的には, 平等主義的な再分配法や, 浜 田・石田（2003）, 石田・浜田（2005）のような機会調整の意味合いをもつもの, あるいは必要に応じた分配がある，その他さまざまな基準による再分配がありうる が，本研究では平等分配が社会的な幸福総和に与える影響に注目したい。 このとき 所得に対する累進課税，そして負の所得税としての補償によって再分配を行うとい うメカニズムを想定する。こうした再分配の仕組みは現行の所得税と社会保障の組 み合わせにおいて部分的に実現している. そして, 累進の度合いを高めることで段 階的に完全平等へと分配を変化させていったとき，平等化の度合いによって平均幸 福がどのように変化するかを分析する.

具体的には, 平均所得と本人所得の差額部分に一律 $t(0 \leq t \leq 1)$ の税率で課税す るという方法を採用する (図 2 ). 再分配前の $i$ の所得を $y_{i}$, 平均所得を $\mu$, 課税率 を $t$ とすると, 個人 $i$ の税額は $t\left(y_{i}-\mu\right)$ であり, 個人 $i$ の所得全体に対する税率 $\tau_{i}$ は $\tau_{i}=t\left(y_{i}-\mu\right) / y_{i}$ となる。 そして, $i$ の再分配後所得は $y^{\prime}{ }_{i}=y_{i}-t\left(y_{i}-\mu\right)$ である. $t \neq 1$ のとき $y^{\prime}{ }_{i}$ は $y_{i}$ の正の 1 次変換であり，再分配前の所得順位は維持される。 こ こで具体例を見てみよう。再分配前所得べクトルを $\boldsymbol{y}=(50,100,200,250,400)$ とし, $t=0.1$ とする. $\mu=200$ である.このとき, 再分配後所得は $\boldsymbol{y}^{\prime}=(65,110,200,245,380)$, 税率は $\tau=(-0.3,-0.1,0,0.02,0.05)$ となる.

ここで採用した平均を基準とした平等化再分配法は，次の 3 つの性質を持ってい る. 第 1 に, 所得総額が不変であること. 第 2 に, 課税の度合いが所得水準に対し て累進性をもつこと. 第 3 に, 再分配前から完全平等までのジニ係数の変化を, 1 つのパラメータによって線形に表現できることである。ジニ係数はよく知られた分 配の不平等度の指数であり, $\boldsymbol{y}=\left(y_{1}, \ldots, y_{n}\right)$ を所得ベクトルとすると, そのジニ係 数は $G(\boldsymbol{y})=\sum_{i=1}^{n} \sum_{j=1}^{n}\left|y_{i}-y_{j}\right| /\left(2 n^{2} \mu\right)$ で定義される. 值が 0 のとき完全平等で, 1 に近づくほど不平等度が高まる。この第 3 の性質はややテクニカルなものであるが, この性質が満たされる場合，そのパラメー夕を変化させ平均幸福の挙動を分析する 


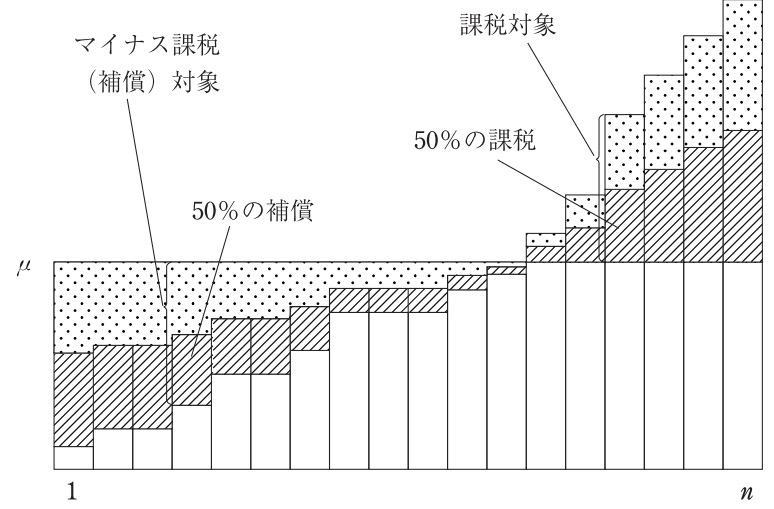

図 2 平均を基準とする平等化再分配法のイメージ図 $(t=0.5)$

ことによって，平等化と幸福の関係を単純な形で分析することができるため，われ われの分析目的にとって好ましい性質である.

平均を基準とした平等化再分配法がこれらの 3 つの性質を持つことを確認してお こう。まず,

$$
\begin{aligned}
\sum_{i=1}^{n} y^{\prime}{ }_{i} & =\sum_{i=1}^{n}\left\{y_{i}-t\left(y_{i}-\mu\right)\right\} \\
& =(1-t) \sum_{i=1}^{n} y_{i}+t \sum_{i=1}^{n} \mu \\
& =(1-t) \sum_{i=1}^{n} y_{i}+t \sum_{i=1}^{n} y_{i}=\sum_{i=1}^{n} y_{i}
\end{aligned}
$$

であり, 所得総額は不変である. 次に, $t \neq 0, y_{i} \neq 0, \mu \neq 0$ で $\mu$ が不変のとき,

$$
\frac{\partial \tau_{i}}{\partial y_{i}}=\frac{\partial}{\partial y_{i}}\left\{\frac{t\left(y_{i}-\mu\right)}{y_{i}}\right\}=\frac{t \mu}{y_{i}{ }^{2}}>0
$$

であるので, 所得に対する税率は累進性をもつ ${ }^{8)}$. また, $\partial \tau_{i} / \partial y_{i}$ は $t$ に比例して大 きくなる，最後に，任意の $i, j$ について，

$$
\begin{aligned}
\left|y^{\prime}{ }_{i}-y_{j}{ }_{j}\right| & =\left|y_{i}-t\left(y_{i}-\mu\right)-\left\{y_{j}-t\left(y_{j}-\mu\right)\right\}\right| \\
& =\left|(1-t)\left(y_{i}-y_{j}\right)\right|=(1-t)\left|y_{i}-y_{j}\right|
\end{aligned}
$$

である，ゆえに，ジニ係数の定義より，再分配後のジニ係数は，

$$
G\left(\boldsymbol{y}^{\prime}\right)=\frac{1}{2 n^{2} \mu}(1-t) \sum_{i=1}^{n} \sum_{j=1}^{n}\left|y_{i}-y_{j}\right|=(1-t) G(\boldsymbol{y})
$$

となり, 平等化再分配後のジニ係数は $t$ について線形に減少することが確認できる.

\section{3 所得 - 生活満足得点関数の推定}

\section{1 推定方法}

シミュレーション分析においては, 次の 2 種類のモデルを扱う. 1 つは, 個人所 得の再分配の効果を検討するためのモデルである。ただし, 女性の場合は既婚者を 中心に無職の者が多く，また就業形態も男性とは異なるので，個人所得の意味合い 
も異なってくる.そこで，ここでは男性サンプルのみを対象とした個人所得再分配 モデルを取り上げる，第 2 のモデルは，世帯所得の再分配を対象とする．ただし， 調査の設計上，回答者がその世帯の代表的な構成員であるとは限らない。そこで, 回答者の表明する生活満足度と世帯の状況との関連づけをはっきりとさせるために, 対象を有配偶者もしくは親と同居していない無配偶者に限定する．この限定によっ て，親と同居する独身の者を除外することになる．

さて，これらのモデルの分析のために本節では，シミュレーション分析に必要と なる所得 - 生活満足得点関数の推定を行う. その際, プロフィールによって生活満 足得点関数が異なるという仮定を採用し，プロフィールを構成する次元を表すダミ 一変数とダミー変数との交互作用を含む線型モデルを用いる.

このとき, 本研究では生活満足得点 $w$ と個人所得 $y$ の基本的な関係を,

$w=a y^{b}$

と仮定する. 式（6）は $0<b<1$ のとき，1階導関数が正， 2 階導関数が負になり, 限界効用聥減法則を組み込んだ反応関数の仮定として自然である. また, 最小二乗 法における分散不均一性の問題を回避しやすいという利点もある. さらに, 式の展 開によって,

$$
b=\frac{d w}{w} / \frac{d y}{y}
$$

を得る.つまり, $b$ は $y$ の増加率に対する $w$ の増加率の比を示す弾性值になってお り, 回帰係数の解釈を容易にする（佐和 1979）. 以上の特性から, 本研究では前述 の仮定を採用する. 式（6）を対数変換すると,

$\log w=\log a+b \log y$

である. 式（8）のそれぞれを $W=\log w, \alpha=\log a, \quad \beta=b, \quad Y=\log y$ と置き換 えると, $W=\alpha+\beta Y$ となり線形回帰式を得る. これに最小二乗法を適用し回帰係 数を推定する. ただし, 所得なし $(y=0)$ を対数変換すると不定形になるため, 実際の回帰分析では各個人所得に 1 を加算する。 さらに，それぞれのモデルではダ ミー変数, そしてダミー変数と対数所得変数との交互作用を含むモデルを検討する.

プロフィールを構成する次元としては, 年齢階層, そして世帯所得モデルでは回 答者の性別という基本属性次元に加えて, 社会経済的地位の次元として教育達成レ ベルを取り上げる，社会経済的地位の次元として教育達成レベルを採用するのは以 下の理由による. 1 つには, 教育レベル (学歴) が他の階層指標と比べて, 高度経 済成長以降の日本社会において, 社会意識と比較的強い結びつきを持っているとい う階層意識研究における知見（吉川 2006）がある.さらに, 主観的幸福研究にお いても教育レベルの効果は検討されてきた，先進諸国では教育達成が主観的幸福に, 強くないが正の効果をもつことが指摘されている（Veenhoven 1984; Diener, et al. 1999; Frey and Stutzer 2000 =2005)．また，低所得者層では教育と幸福の結びつき が強くなるとの知見（Diener, et al. 1993）や，アスピレーションレベルの影響で高 学歴者はそうでないものに比べて, 失業という経済状況の変化に, より強い不満を 
表 2 男性個人所得モデル

\begin{tabular}{l|ccc}
\hline & 非標準化係数 & 標 準 誤 差 & 有 意 確 率 \\
\hline (定数) & $0.797 * *$ & 0.048 & 0.000 \\
個人所得 (対数) & $0.064 * *$ & 0.008 & 0.000 \\
短大 以上 & $0.414 * *$ & 0.072 & 0.000 \\
60歳代 $\times$ 高校 & $0.061 *$ & 0.026 & 0.018 \\
短大以上 $\times$ 個人所得 & $-0.041^{* *}$ & 0.012 & 0.001 \\
50 歳代 $\times$ 短大以上 & $-0.632 * *$ & 0.141 & 0.000 \\
50 歳代 $\times$ 短大以上 $\times$ 個人所得 & $0.086 * *$ & 0.023 & 0.000 \\
40 歳代 & $-0.607 * *$ & 0.105 & 0.000 \\
40 歳代 $\times$ 個人所得 & $0.088 * *$ & 0.017 & 0.000 \\
高 校 & $0.071 * *$ & 0.024 & 0.003 \\
\hline 調整済み $R^{2}$ & \multicolumn{3}{|c}{0.094} \\
$F$ 值 & & $27.201 * *$ \\
\hline
\end{tabular}

(注) 目的変数：生活満足得点 (対数) $N=2271, * p<0.01, * * p<0.05$

表 3 各プロフィールの推定反応関数（個人所得）

\begin{tabular}{c|c|c|c}
\hline \multirow{2}{*}{ 年齢階層 } & \multicolumn{3}{|c}{ 教育達成レベル } \\
\cline { 2 - 4 } & 中 学 卒 & 高 校 卒 & 短大以上卒 \\
\hline 20歳代 & $w=2.218 y^{0.064}$ & $w=2.381 y^{0.064}$ & $w=3.355 y^{0.023}$ \\
30歳代 & $w=2.218 y^{0.064}$ & $w=2.381 y^{0.064}$ & $w=3.355 y^{0.023}$ \\
40 歳代 & $w=1.209 y^{0.152}$ & $w=1.297 y^{0.152}$ & $w=1.828 y^{0.111}$ \\
50 歳代 & $w=2.218 y^{0.064}$ & $w=2.381 y^{0.064}$ & $w=1.784 y^{0.109}$ \\
60 歳代 & $w=2.218 y^{0.064}$ & $w=2.530 y^{0.064}$ & $w=3.355 y^{0.023}$ \\
\hline
\end{tabular}

感じるという知見（Clark and Oswald 1994）もあり，教育レベルが所得や年齢と 交互作用をもつ可能性がある。これらの理由により，ここではプロフィールを構成 する 1 次元として教育達成レベルを取り上げる ${ }^{9)}$.

\section{2 男性個人所得モデル}

最初に, 男性サンプルのみを対象にした個人所得の再分配モデルのための, 満足 得点関数の推定を実施する. 年齢階層は 20 歳代（20 歳〜29 歳）から 60 歳代（60 歳〜69 歳）までの 6 つのカテゴリに分割し，20歳代を基準カテゴリとしてダミー 変数 $A_{i}$ を作成する. 教育レベルは中学校卒, 高校卒, 短大 ·高専 · 大学・大学院 卒の 3 カテゴリとし, 中学校卒を基準カテゴリとしてダミー変数 $E_{i}$ を作成する.

このとき，検討するモデルは次のように表すことができる.

$$
\begin{aligned}
W & =\alpha+\beta_{1} Y+\sum_{i} \beta_{2 i} A_{i}+\sum_{j} \beta_{3 j} E_{j}+\sum_{i} \beta_{4 i} A_{i} Y+\sum_{j} \beta_{5 j} E_{j} Y \\
& +\sum_{i} \sum_{j} \beta_{6 i j} A_{i} E_{j}+\sum_{i} \sum_{j} \beta_{7 i j} A_{i} E_{j} Y
\end{aligned}
$$

これを生活満足得点 $w$ の予測式に直すと,

$$
w=\exp \left\{\alpha+\sum_{i} \beta_{2 i} A_{i}+\sum_{j} \beta_{3 j} E_{j}+\sum_{i} \sum_{j} \beta_{6 i j} A_{i} E_{j}\right\} y^{\hat{\beta}}
$$




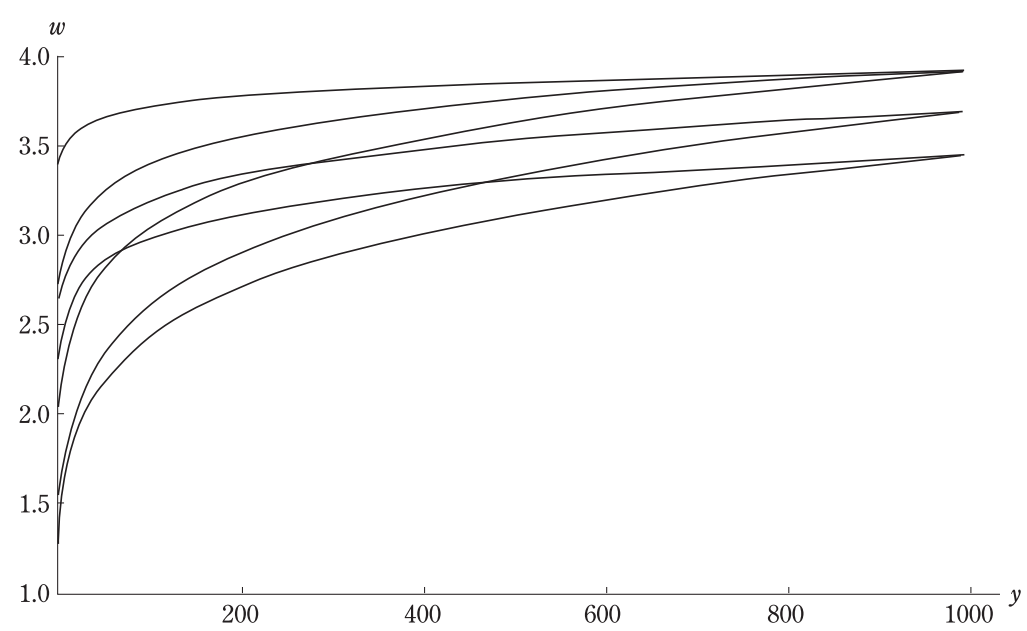

図 3 男性個人所得モデル推定反応関数

である.ただし， $\hat{\beta}=\beta_{1}+\sum_{i} \beta_{4 i} A_{i}+\sum_{j} \beta_{5 j} E_{j}+\sum_{i} \sum_{j} \beta_{7 i j} A_{i} E_{j}$ である. 分析では $\beta_{1} Y$ を除くすべての項を対象にしてステップワイズ法 $\left(p_{\text {in }}=0.10, p_{\text {out }}=0.15\right)$ を実施し, 効率的なモデルを選択した. 分析にあたって, 個人所得 2,500 万円以上 （有効サンプルの 0.08\%）は飛び值として除外した. 表 2（759 頁）は分析結果を 示している.

各年齢階層ダミーと個人所得との交互作用効果が見られた。調整済み決定係数は 0.094 であり, あまり高くない. そして, 表 3（759 頁）は推定された係数をもと に, 各プロフィールの推定反応関数を示したものである. 生活満足得点の所得弾力 性が最も高い, すなわち所得に対する満足得点の反応が最も強いのは 40 歳代, 特 に中学校卒・高校卒の 40 歳代であった。 逆に, $20 \cdot 30 \cdot 60$ 歳代の短大以上卒では 基礎得点は高いものの, 所得と満足得点の間の関連性はわずかであった. 図 3 は, 各プロフィールの推定反応関数を描き出している.

\section{3 世帯所得モデル}

次に，有配偶者もしくは親と同居していない無配偶者の世帯所得再分配モデルの ための, パラメータ推定を実施する. プロフィールの次元としては, 回答者の年齢 階層と性別, そして教育達成レベルを取り上げる。世帯有配偶者の場合は夫婦の学 歴の高いほうを世帯教育達成レベルとする，女性ダミー変数を $F$ とすると，モデ ルは,

$$
\begin{aligned}
W & =\alpha+\beta_{1} Y+\beta_{2} F+\sum_{i} \beta_{3 i} A_{i}+\sum_{j} \beta_{4 j} E_{j}+\beta_{5} F Y+\sum_{i} \beta_{6 i} A_{i} Y+\sum_{j} \beta_{7 j} E_{j} Y \\
& +\sum_{i} \beta_{8 i} F A_{i}+\sum_{j} \beta_{9 j} F E_{j}+\sum_{i} \sum_{j} \beta_{10 i j} A_{i} E_{j}+\sum_{i} \beta_{11 i} F A_{i} Y+\sum_{j} \beta_{12 j} F E_{j} Y \\
& +\sum_{i} \sum_{j} \beta_{13 i j} A_{i} E_{j} Y+\sum_{i} \sum_{j} \beta_{14 i j} F A_{i} E_{j} Y+\sum_{i} \sum_{j} \beta_{15 i j} F A_{i} E_{j} Y
\end{aligned}
$$


表 4 世帯所得モデル

\begin{tabular}{|c|c|c|c|}
\hline & 非標準化係数 & 標準誤差 & 有意確率 \\
\hline (定数) & $0.713 * *$ & 0.058 & 0.000 \\
\hline 世帯所得（対数） & $0.077 * *$ & 0.010 & 0.000 \\
\hline 短大以上 & $0.149 * *$ & 0.023 & 0.000 \\
\hline 女 性 & $0.069 * *$ & 0.013 & 0.000 \\
\hline 60 歳代 $\times$ 短大以上 & $0.384 *$ & 0.191 & 0.044 \\
\hline 60 歳代 $\times$ 短大以上 $\times$ 世帯所得 & -0.058 & 0.031 & 0.057 \\
\hline 高校×世帯所得 & $0.016 * *$ & 0.003 & 0.000 \\
\hline 30歳代 $\times 女$ 性 & $-0.576 *$ & 0.238 & 0.016 \\
\hline 40歳代 & $-0.430 * *$ & 0.144 & 0.003 \\
\hline 50歳代 & $-0.233 *$ & 0.090 & 0.010 \\
\hline 30歳代 $\times 女$ 性 $\times$ 世帯所得 & $0.084 *$ & 0.038 & 0.028 \\
\hline 40歳代 $\times 世$ 帯所得 & $0.052 *$ & 0.023 & 0.021 \\
\hline 50歳代 $\times 世$ 帯所得 & 0.024 & 0.015 & 0.098 \\
\hline 調整済み $R^{2}$ & & 0.095 & \\
\hline$F$ 值 & & $31.385 * *$ & \\
\hline
\end{tabular}

(注) 目的変数：生活満足得点 (対数) $N=3488, * p<0.01, * * p<0.05$

表 5 各プロフィールの推定反応関数（世帯所得）

\begin{tabular}{|c|c|c|c|c|}
\hline & & \multicolumn{3}{|c|}{ 教育達成レベル } \\
\hline & & 中学校卒 & 高校卒 & 短大以上卒 \\
\hline \multirow{5}{*}{ 男 性 } & 20歳代 & $w=2.040 y^{0.077}$ & $w=2.040 y^{0.093}$ & $w=2.368 y^{0.077}$ \\
\hline & 30歳代 & $w=2.040 y^{0.077}$ & $w=2.040 y^{0.093}$ & $w=2.368 y^{0.077}$ \\
\hline & 40歳代 & $w=1.328 y^{0.130}$ & $w=1.328 y^{0.146}$ & $w=1.541 y^{0.130}$ \\
\hline & 50歳代 & $w=1.615 y^{0.102}$ & $w=1.615 y^{0.118}$ & $w=1.875 y^{0.102}$ \\
\hline & 60歳代 & $w=2.040 y^{0.077}$ & $w=2.040 y^{0.093}$ & $w=3.477 y^{0.019}$ \\
\hline \multirow{5}{*}{ 女 性 } & 20歳代 & $w=2.186 y^{0.077}$ & $w=2.186 y^{0.093}$ & $w=2.537 y^{0.077}$ \\
\hline & 30歳代 & $w=1.229 y^{0.161}$ & $w=1.229 y^{0.177}$ & $w=1.426 y^{0.161}$ \\
\hline & 40歳代 & $w=1.423 y^{0.130}$ & $w=1.423 y^{0.146}$ & $w=1.651 y^{0.130}$ \\
\hline & 50歳代 & $w=1.731 y^{0.102}$ & $w=1.731 y^{0.118}$ & $w=2.008 y^{0.102}$ \\
\hline & 60歳代 & $w=2.186 y^{0.077}$ & $w=2.186 y^{0.093}$ & $w=3.724 y^{0.019}$ \\
\hline
\end{tabular}

と表される. 先と同様に分析では $\beta_{1} Y$ 以外の項に対してステップワイズ法 $\left(p_{\text {in }}=0.10, p_{\text {out }}=0.15\right)$ を用いて効率的なモデルを選択した．なお，世帯所得 について, 親と同居していない無配偶者であって世帯所得が DK/NA の場合は, 個人所得を代入した。 さらに，世帯所得 3,500 万円以上（有効サンプルの $0.09 \%$ ） は飛び值として除外した．表 4 に分析結果を示す.

各年齢階層ダミーと世帯所得との交互作用効果が見られた。調整済み決定係数は 0.095 であった. 表 5 は各プロフィールの推定反応関数を示したものである. 生活 


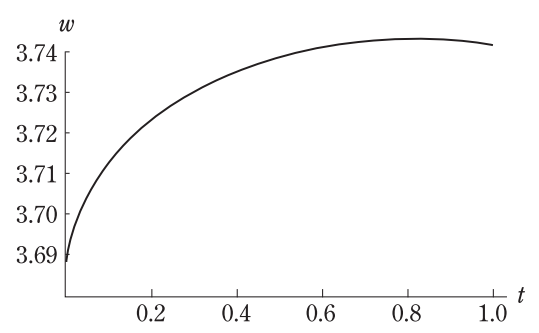

図 $4 t$ による平均満足得点の変化 (個人所得)

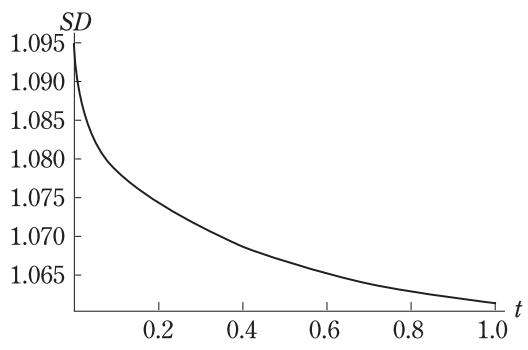

図 $5 t$ による満足得点の標準偏差の変化 (個人所得)

満足得点の所得弾力性が比較的高いのは, 個人所得の場合と同様 40 歳代であった. また，女性の 30 歳代も高い值を示している。これらの年代において，子育て費用 や住宅ローンなど世帯の必要所得が他の年代に比べて高まることが, 弾性值の高さ の理由の 1 つであると考えられる.

\section{4 シミュレーション結果}

\section{1 男性個人所得モデル}

以下では，男性個人所得モデルのシミュレーション分析結果を示す．パラメータ $t$ と生活満足得点の平均との関連を中心に検討することになるが, 同時に生活満足 得点の標準偏差の結果にも注目する。主観的幸福研究の枠組みにおいて, 幸福感の 社会的不平等が焦点化されることがある，主観的幸福尺度は基本的に質問紙調查に おける意識尺度であるので, 比率尺度であるとは見なし得ない. ゆえに, 不平等度 を測る尺度としては，ジ二係数などの経済的不平等指数よりも標準偏差の方が好ま しい特性を持っているとされる（Kalmijn and Veenhoven 2005; Veenhoven 2005). ここでも所得の不平等と幸福の不平等との関連を, パラメータ $t$ と生活満足得点の 標準偏差の関連を見ることによって検討する.

分析結果を示そう. 分析に用いられた有効サンプル数は 2,272 で, 平均所得は 442.863 万円，平均所得の累積％は $61.36 \%$ でった。つまり単純に言って，平均 を基準とする平等化再分配法を適用した場合，6割以上の人々が所得補償の恩恵を 受けることになる. 再分配前, つまり $t=0$ のときのジニ係数は 0.360 , 平均生活 満足得点は 3.680 , 生活満足得点の標準偏差は 1.095 であった. 図 4 は $t$ による平 均生活満足得点の変化, 図 5 は生活満足得点の標準偏差の変化を示している.

具体的に平均生活満足得点の挙動を確認しよう。平均生活満足得点は $t$ の増加に 対して, 増加した後 0.6 以降ほとんど増加せず飽和し, その後減少するという挙動 を示す. 最小值は $t=0$ のとき, 最大值は $t=0.822$ のときの 3.744 , そして最大

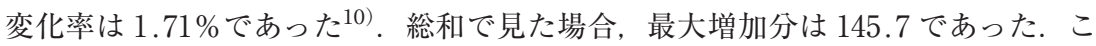


の状況は，仮に生活満足得点の個人間移転が可能であったとすると，他の人たちの 満足感を減らすことなく少なくとも 145 人（有効サンプルの $6.38 \%$ ）の満足得点 を 1 上昇させることができる，もしくは全員に 0.06 のプラスの満足感を与えるこ とができる，ということを示している．この結果の評価は見方によって異なりうる が, 大まかに言えば, $t$ の変動が平均生活満足得点を大幅に改善させることはなか ったと言えるだろう。また，平均生活満足得点が最大になるときのジニ係数は 0.064，標準偏差は 1.063 であった。 ところで，飽和点における実際の税率はどの 程度であろうか. 個人所得 1,000 万円の場合, $t=0.822$ のとき税率は $45.84 \%$ で ある ${ }^{11)}$. さらに, 生活満足得点の標準偏差は $t$ の増加につれて単調減少した。つま

り, 所得の平等化にしたがって幸福も平等化するのである.

\section{2 世帯所得モデル}

次に，有配偶者もしくは親と同居していない無配偶者の世帯所得の再分配モデル の結果を示す。分析に用いられた有効対象サンプル数は 3,487 で, 平均所得は 603.352 万円，平均所得の累積％は $64.181 \%$ であった，再分配前，つまり $t=0$ の ときのジニ係数は 0.346 , 平均生活満足得点は 3.818 , 生活満足得点の標準偏差は 1.066 であった. 図 6（764 頁）は $t$ による平均生活満足得点の変化, 図 7 (764 頁）は生活満足得点の標準偏差の変化を示している.

個人所得モデルとは異なり, 平均生活満足得点は $t$ に対して 0.8 あたりまでは単 調な増加を示している. 最小值は $t=0$ のとき, 最大值は $t=0.929$ のときの 3.891 ，そして最大変化率は $1.876 \%$ であた。総和で見た場合，最大増加分は 254.53 で，仮に生活満足得点の世帯間移転が可能であったとすると，他の世帯の 満足感を減らすことなく少なくとも 254 世帯（有効サンプルの $7.28 \%$ ）の満足感 を 1 上昇させることができることになる。これは男性に限った個人所得の再分配の 場合と比べて, 世帯所得の再分配の方が生活満足得点総和の改善の効果が若干なが ら強いことを示しているものの，やはり効果は限定的であると言えるだろう。平均 生活満足得点が最大になる $t=0.929$ のとき, ジニ係数は 0.024 , 標準偏差は 1.032 ，そしてこのとき所得 1,000 万円の場合の税率は $36.96 \%$ であた。標準偏 差は $t$ の増加にしたがって減少するものの, $t=0.915$ のとき最小值の 1.032 をと り，その後微増する結果となった。

\section{5 結論と今後の展望}

本研究によって得られた主要な知見を確認しておこう。個人所得モデルでは, 平 等化によってジニ係数を $60 \%$ 近く下げたところで改善効果がほとんどなくなり, $82 \%$ のたりで飽和点が見られた。 また，世帯所得モデルにおいても $92 \%$ あたり で飽和点が観察された。この結果は，効率的に幸福を高めることを目的とする場合 は，適度な平等分配が効果的であることを示唆している．個人所得モデルの場合よ 


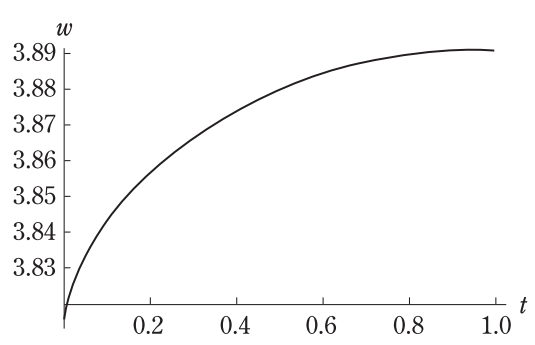

図 $6 t$ による平均満足得点の変化 (世帯所得)

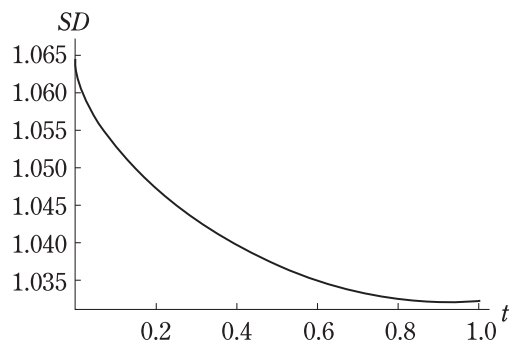

図 $7 t$ による満足得点の標準偏差の変化 (世帯所得)

りも，世帯所得モデルにおいて，より大きな改善効果が確認されたものの，それら の効果自体は決して大きなものではなく, 全体的に所得再分配による社会的幸福へ の効果は限定的であると言わざるを得ない.このことは結果的に, 所得の再分配の みでは社会的幸福の促進は不十分であり，社会的幸福の促進のためには，人々の幸 福に関連する他の施策と再分配政策とを効果的に連携していく必要があることを示 唆していると言えるだろう。

今後の課題として以下が挙げられる，1つの方向性は, さまざまな分配原理の効 果測定に本手法を応用することである，もう1つの方向性は，分析枠組みそのもの を精緻化していくことである，まずは，主観的幸福の指標として，生活満足得点の 他にも別の妥当な尺度を用いることを検討する必要がある。そして，所得について の幸福関数について, さらなる要因を考慮して推定の精度を上げることも必要であ る。そしてそれだけではなく，幸福関数の定義をさらに工夫して，人々の認識上の 特性を織り込んだ関数を用いることも興味深い課題になるだろう。例えば，これま での主観的幸福の時系列比較研究では, マクロレベルでもミクロレベルのパネルデ ータでも，主観的幸福レベルは所得レベルの上昇とほとんど関連しないことがしば しば報告されている (Diener and Biswas-Diener 2002; Frey and Stutzer 2000= $2005)^{12)}$. こうした知見に対して, 野心レベルの変化（Easterlin 2001）や他者の所 得との相対比較というメカニズムによる説明が提案されている. 特に, 相対比較は 社会学における準拠集団や相対的剝奪という問題と関連して興味深い. 所得に対す る効用を，個人の所得レベルと準拠集団の平均の比についての単調増加関数とする R. Easterlin（1974）の提案や，浜田宏（2001）の $\delta$ 区間モデルなどを踏まえて, こうしたメカニズムを組み込んだシミュレーションモデルを構築することによって， さらに興味深いインプリケーションを引き出すことができるだろう.

[付記］本稿はSSM 調查報告書所収の石田（2008）における分析手法を見直し, 議論をさらに 発展させたものである，論文の修正にあたっては匿名の查読者からのコメントが有用であった．記 して感謝したい. 2005 年 SSM 日本調查データの使用については 2005 年社会階層と社会移動調查研 
究会の許可を得た。また, 2005 年 SSM 日本調查のデータセットは 2007 年 11 月配布の第 4 次配布 版（最終版）を使用した，本稿は，平成 18〜20 年度科学研究費補助金（特別研究員奨励費）によ る研究成果の一部である.

\section{[注]}

1）以下, 本稿で「所得」という場合は税制上の厳密な意味ではなく,「収入」と同義的な用語 として用いる. また, 分析において用いる SSM 調查データの収入項目は, 年金や配当金を含 んだすべての課税前収入である.

2）他にも世界価值観調查などに見られるように, 幸福かどうかを直接尋ねる項目を用いる場合 がある，あるいは，幸福項目と満足項目を組み合わせた操作的定義が用いられることもある (Inglehart 1997).

3）個人所得階層の代表値として回答カテゴリの中央值を割り当てた. ただし，サンプル数の都 合上，1,000 万円から 1,400 万円位，1,500 万円から 1,900 万円位，2,000 万円位以上はそれぞ れ同一カテゴリにまとめた。

4) 個人 $i$ の所得を $y_{i}$, 効用関数を $u_{i}$ とする. 効用関数は連続で微分可能, 狭義単調増加の準凹 関数とする. 功利主義的社会厚生関数を $W(\boldsymbol{y})=\Sigma u_{i}\left(y_{i}\right)$ とすると, $W$ の最大化問題は,

$$
\max _{y} W(\boldsymbol{y}) \text { subject to } B=\Sigma y_{i}
$$

である. $B$ は総所得で定数. この最大化問題の 1 階の条件は, 制約条件のもとで,

$$
\frac{d u_{1}}{d y_{1}}=\frac{d u_{2}}{d y_{2}}=\cdots=\frac{d u_{n}}{d y_{n}}
$$

が成立することである，ここで $u_{1}=u_{2}=\cdots=u_{n}$ とすると， 1 階の条件を満たすのは, 全員に $B / n$ を配分するという平等分配である.

5） A. Sen（1997=2000：21-3）も指摘するように, 功利主義的社会厚生関数は不平等の基準と しては不適当である。ただし，ここでは再分配に対する人々の「実際の」反応の指標として用 いるのであり, この点では高い有用性をもつと考えている，また，本研究は直接的には最適問 題の形にはなっていないが, 本研究の知見を最適分配の視点から評価することも可能である.

6）再分配コストによって再分配後総所得にある程度のロスが生じるという機制も考えられ，モ デルの発展においてそのような仮定をおくことも可能であるが, ここではもっとも単純な仮定 を採用する。

7）実際には生活満足得点のレンジを超える推定值もあり得る。そこで,レンジを超えた場合, レンジの最大值 $w_{\max }$ もくは最小值 $w_{\min }$ をとると仮定し, 推定式

$$
w_{r i}{ }^{\prime}=\max \left\{\min \left\{\left[w_{r i}+f_{r}\left(y_{r i}^{\prime}\right)-f_{r}\left(y_{r i}\right)\right], w_{\max }\right\}, w_{\min }\right\}
$$

を用いることも可能である. 実際には後の分析において, レンジの制限を設けても結果の傾向 性はほとんど変わらないため,（1）式を推定式として採用する.

8）ここで， $\partial \tau_{i} / \partial y_{i}$ は累進度の指標の 1 つである平均税率累進度（average rate progression）に 対応する (Musgrave and Thin 1948).

9）関連して, 教育達成レベルがディストレスに負の効果を持つとの知見がある（Ross and Van Willigen 1997)。また, 教育レベルは, 国別のウェル・ビーイングの指標として国連開発計画 において定式化された指標である，人間開発指標（HDI）において，生存・経済的豊かさとと もに，潜在能力を高め，生き方の幅を担保する要因として取り上げられている.

10）最大変化率は平均幸福のレンジ 4 と, パラメー夕 $t$ を動かしたときの平均幸福最大值と最小 值の差の比率である. 
11）所得概念が異なるために厳密な対応にはなっていないものの, 2008 年現在の 900 万円以上 1,800 万円以下の所得に対する所得税率は $33 \%$ ，住民税を併せると $43 \%$ あるる.

12）ただし，いくつかの発展途上国では，経済成長につれて主観的幸福レベルが上昇するという 関係が見出される（Hagerty and Veenhoven 2003）。

\section{[文献]}

Clark, Andrew E. and Andrew J. Oswald, 1994, "Unhappiness and Unemployment," The Economic Journal, 104: 648-59.

Diener, Ed, Ed Sandvik, Larry Seidlitz and Marissa Diener, 1993, “The Relationship between Income and Subjective Well-being: Relative or Absolute?” Social Indicators Research, 28 (3): 195-223.

- Eunkook M. Suh, Richard E. Lucas and Heidi L. Smith, 1999, "Subjective Well-Being: Three Decades of Progress,” Psychological Bulletin, 125 (2): 276-302.

and Robert Biswas-Diener, 2002, "Will Money Increase Subjective Well-Being?: A Literature Review and Guide to Needed Research," Social Indicators Research, 57 (2): 119-69. Easterlin, Richard A., 1974, "Does Empirical Growth Improve the Human Lot? Some Empirical Evidence," Paul A. David and Melvin W. Reder eds., Nations and Households in Economic Growth: Essays in Honor of Moses Abramovitz, New York: Academic Press, 89-125.

- 2001, "Income and Happiness: Towards a Unified Theory," The Economic Journal, 111: $465-84$.

Frey, Bruno S. and Alois Stutzer, 2002, Happiness and Economics: How the Economy and Institutions Affect Human Well-being, Princeton: Princeton University Press. (= 2005, 佐和隆光監訳・沢 崎冬日訳, 『幸福の政治経済学—人々の幸せを促進するものは何か』ダイヤモンド社. )

Hagerty, Michael R. and Ruut Veenhoven, 2003, “Wealth and Happiness Revisited: Growing National Income Does Go with Greater Happiness,” Social Indicator Research, 64: 1-27.

浜田宏, 2001, 「経済的地位の自己評価と準拠集団— $\delta$ 区間モデルによる定式化」『社会学評論』 52 (2): 283-99.

- 石田淳, 2003, 「不平等社会と機会の均等——機会格差調整後の不平等度測定法」『社会 学評論』54 (3): 232-49.

Inglehart, Ronald, 1997, Modernization and Postmodernization: Cultural, Economic, and Political Change in 43 Countries, Princeton: Princeton University Press.

石田淳, 2008, 「所得分配の不平等度と幸福総和の関連—シミュレーション分析の試み」土場学 編『公共性と格差』(2005 年 SSM 調查シリーズ 7), 57-70.

・浜田宏, 2005,「仮想的機会調整分析による不平等分析——ブートストラップ法による 機会調整前後のジニ係数の有意差検定」『理論と方法』20(1): 109-25.

Kalmijn, Wim, and Ruut Veenhoven, 2005, “Measuring Inequality of Happiness in Nations: In Search for Proper Statistics,” Journal of Happiness Studies, 6: 357-96.

吉川徹, 2006, 『学歴と格差・不平等——成熟する日本型学歴社会』東京大学出版会.

小西砂千夫, 1997, 『日本の税制改革一一最適課税論によるアプローチ』有斐閣.

Musgrave, R. A., and Tun Thin, 1948, “Income Tax Progression, 1929-48," The Journal of Political Economy, 56 (6): 498-514.

村上雅子, 1972, 『最適分配の経済学——公共経済学の基礎理論』新評論.

大竹文雄, 2004, 「失業と幸福度」『日本労働研究雑誌』528: 56-68. 
Roemer, John E., 1996, Theories of Distributive Justice, Cambridge: Harvard University Press. (= 2001，木谷忍・川本隆史訳『分配的正義の理論——経済学と倫理学の対話』木鐸社. )

-, 1998, Equality of Opportunity, Cambridge: Harvard University Press.

Ross, Catherine E. and Marieke Van Willigen, 1997, "Education and the Subjective Quality of Life," Journal of Health and Social Behavior, 38 (3): 275-97.

佐和隆光, 1979, 『回帰分析』朝倉書店.

Sen, Amartya K., 1997, On Economic Inequality, expanded edition with a substantial annex by James E. Foster and Amartya Sen, Oxford: Clarendon Press. (=2000，鈴村興太郎 - 須賀晃一訳『不 平等の経済学』東洋経済新報社.)

Veenhoven, Ruut, 1984, Conditions of Happiness, Dordrecht, Holland: D. Reidel.

, 2005, "Return of Inequality in Modern Society? Test by Dispersion of Life-satisfaction across Time and Nations," Journal of Happiness Studies, 6: 457-87.

, 2007, “Subjective Measures of Well-being," Mark McGillivray ed., Human Well-being: Concept and Measurement, Basingstoke: Palgrave Mcmillan, 214-39.

（原稿受付 2007.9.11 掲載決定 2008.8.29） 


\title{
Change in Inequality and Aggregation of Subjective Well-being by Redistribution of Income:
}

A simulation analysis using the 2005 SSM survey dataset

\author{
ISHIDA, Atsushi \\ Research Fellow of the Japan Society for the Promotion of Science \\ aishida@kwansei.ac.jp
}

Recently, normative studies on distribution principles have begun to attract the attention of many sociologists. I would like to propose a sociological research program that can contribute to these normative discussions. The research program I propose aims to estimate various social influences that are a result of the application of a certain distribution principle. On the basis of this concept, this study aims to simulate a change in the aggregation of subjective well-being through the virtual redistribution of income using the 2005 Social Stratification and Social Mobility (SSM) Survey dataset. In this article, I apply the egalitarian redistribution method so as to analyze the relationship between the reduction of inequality and aggregation of subjective well-being. At first, the function of subjective wellbeing (life satisfaction score) to income is presumed from the data according to an individual socio-economic profile. Subsequently, using these functions, the change in the aggregation of subjective well-being by certain redistribution is estimated.

As a result of the analysis, two main findings are obtained. First, in both the redistribution of individual income model and the family income model, the effect of the egalitarian redistribution of income on the aggregation of subjective well-being is restrictive. Second, a moderate equalized redistribution results in maximum increase of the social aggregation of subjective well-being. This suggests that a moderate equal distribution is effective for the purpose of the efficient improvement of societal well-being.

Key word: redistribution of income, subjective well-being, inequality

(Received September 11, 2007 / Accepted August 29, 2008) 